\title{
Curcumin upregulates transforming growth factor- $\beta 1$, its receptors, and vascular endothelial growth factor expressions in an in vitro human gingival fibroblast wound healing model
}

Auspreeya Rujirachotiwat ${ }^{1,2}$ and Supaporn Suttamanatwong ${ }^{3^{*}}$

\begin{abstract}
Background: Curcumin accelerates healing of oral wounds; however, the responsible mechanisms remain underexplored. Our hypothesis is curcumin regulates the expression of wound healing-related genes in human gingival fibroblasts (hGFs). This study investigated whether curcumin regulates transforming growth factor (TGF)- $\beta 1$, type I TGF- $\beta$ receptor (TGF- $\beta R I$ ), type II TGF- $\beta$ receptor (TGF- $\beta R I I)$, and vascular endothelial growth factor (VEGF) expression in unwounded hGFs and an in vitro hGF wound healing model.
\end{abstract}

Methods: The cytotoxicity of curcumin was evaluated using the MTT assay. Unwounded hGFs were treated with non-cytotoxic concentrations of curcumin for $24 \mathrm{~h}$. Gene expression was determined by quantitative polymerase chain reaction. Then, hGFs were treated with $1 \mu \mathrm{M}$ curcumin in an in vitro wound healing model. PD98059 pretreatment was performed to determine whether extracellular signal-regulated kinase (ERK) signaling was required for regulation of gene expression by curcumin.

Results: Curcumin at 0.1-20 $\mu \mathrm{M}$ caused no significant change in cell viability. In unwounded hGFs, curcumin had no significant effect on TGF- $\beta 1$, TGF- $\beta R$ I, TGF- $\beta R I l$, or VEGF expression. Conversely, curcumin significantly upregulated the expression of these genes in the in vitro wound healing model. PD98059 significantly attenuated the curcuminstimulated TGF- $\beta R I$, TGF- $\beta R I I$, and VEGF expression, whereas it had no effect on TGF- $\beta 1$ expression.

Conclusions: Curcumin upregulated TGF- $\beta 1$, TGF- $\beta R I$, TGF- $\beta R I I$, and VEGF expression in an in vitro hGF wound healing model. The ERK pathway is required for TGF- $\beta$ RI, TGF- $\beta$ RII, and VEGF induction by curcumin. Our findings support the development of curcumin as a therapeutic agent for gingival ulcers.

Keywords: Curcumin, Gingiva, Fibroblasts, Wound healing, Vascular endothelial growth factor, Transforming growth factor beta

*Correspondence: supaporn0067@gmail.com

${ }^{3}$ Department of Physiology, Faculty of Dentistry, Chulalongkorn

University, Bangkok 10330, Thailand

Full list of author information is available at the end of the article

\section{Background}

Gingival wound healing is a complex process regulated by signals from several cell types, including immune cells, fibroblasts, endothelial cells, and keratinocytes [1]. The wound healing processes comprises four stages: (1) hemostasis, (2) inflammation, (3) proliferation, and (4) remodeling [2]. Gingival fibroblasts play an important role in the proliferative phase of wound healing 
by secreting multiple cytokines, growth factors, and extracellular matrix, including transforming growth factor beta (TGF- $\beta$ ), vascular endothelial growth factor (VEGF), epidermal growth factor, fibroblast growth factor, and collagen [3], all of which are critical for wound healing [4].

TGF- $\beta$, the prototype cytokine of its family, is produced by activated macrophages, platelets, keratinocytes and fibroblasts [5-8]. The cytokine plays important roles in regulating many cellular functions [9]. Specifically, TGF- $\beta 1$ promotes wound healing by initiating inflammation, forming granulation tissue, and stimulating collagen synthesis and wound contraction [10-12]. Although the three TGF- $\beta$ isoforms (TGF- $\beta 1$, TGF- $\beta 2$, and TGF- $\beta 3$ ) share $60-80 \%$ structural similarity, they are encoded by different genes. These isoforms are secreted as inactive molecules that are activated prior to binding to their specific receptors, type I TGF- $\beta$ receptor (TGF- $\beta$ RI) and type II TGF- $\beta$ receptor (TGF- $\beta$ RII) [13].

The VEGF family comprises VEGF-A, VEGF-B, VEGFC, VEGF-D, and placental growth factor [14]. VEGF is produced by platelets, neutrophils, endothelial cells, fibroblasts, and macrophages [15-19]. VEGF was initially identified as a vascular permeability factor that recruits inflammatory cells. VEGF is upregulated during wound healing [20]. VEGF promotes angiogenesis and granulation tissue formation in the proliferative phase of wound healing by stimulating endothelial cells to proliferate and form new blood vessels [21]. VEGF also has critical roles in inflammation, re-epithelialization, and scar tissue formation [21].

Curcumin (diferuloylmethane), which belongs to the curcuminoid family, is a major constituent of turmeric rhizome that is responsible for its yellow color [22]. Curcumin has long been used as a spice and medicinal herb [23]. Curcumin has anti-bacterial, anti-inflammatory, anti-oxidant, and anti-carcinogenic properties [24-27]. Curcumin has been shown to stimulate dermal and oral wound healing in animal models and clinical studies [28-32]. Curcumin promoted fibroblast proliferation and increased the level of antioxidant enzymes in rat dermal wounds [28, 31]. Furthermore, curcumin enhanced collagen production and reduced matrix metalloproteinase- 9 production in rat cutaneous wounds [32]. When used to treat oral wounds, curcumin accelerated the healing of mucosal ulcers on the upper labial gingiva of rabbits [29]. Clinically, topical curcumin gel notably reduced the size of minor aphthous ulcers compared with a placebo [30]. Although curcumin has demonstrated remarkable wound healing properties, the cellular response to curcumin treatment during oral wound healing remains unclear.
Previous studies found that curcumin regulated gene expression by modulating enzyme activity and signaling pathways, such as mitogen-activated protein kinase (MAPK) [33, 34]. However, little is known about the effects of curcumin on gene expression in gingival fibroblasts and the responsible signaling pathways. Therefore, we examined the effect of curcumin and extracellular signal-regulated kinase (ERK) inhibitor on TGF- $\beta 1$, TGF$\beta R I$, TGF- $\beta$ RII, and VEGF expression using an in vitro human gingival fibroblast (hGF) wound healing model.

\section{Methods \\ Cell culture}

HGFs were isolated from the healthy gingival tissue explants of three donors (two men and one woman; mean age, 21.3 years) who underwent surgical extraction of their third molars. Informed consent forms were obtained from all subjects. The study protocol was approved by the Ethics Committee of the Faculty of Dentistry, Chulalongkorn University.

Isolation of hGFs was performed as previously described [35]. Briefly, the explants were immediately transferred in ice-cold Dulbecco's Modified Eagle's Medium (DMEM) (Sigma-Aldrich, St. Louis, MO, USA) containing $10 \%$ fetal bovine serum (FBS, Gibco, Waltham, MA, USA). The collected gingival tissues were washed with phosphate-buffered saline (PBS, Gibco). The specimens were cut into $1 \mathrm{~mm}^{2}$ pieces and cultured in DMEM containing $10 \% \mathrm{FBS}$ at $37^{\circ} \mathrm{C}$ in a humidified $5 \% \mathrm{CO}_{2}$ atmosphere. Primary hGFs from the third to fifth passage were used in the experiments. Three donor cell lines were used in each independent experiment.

\section{Curcumin preparation}

Curcumin (Sigma-Aldrich) was dissolved in dimethyl sulfoxide (DMSO, Sigma-Aldrich), due to its very low solubility in water, per the manufacturer's instructions. The final concentration of DMSO was $0.1 \%$ in all experiments.

\section{Cell viability assay}

HGFs were seeded at $5 \times 10^{3}$ cells/well in 96-well flatbottomed tissue culture plates in DMEM containing $10 \%$ FBS for $24 \mathrm{~h}$. The medium was replaced with serum-free DMEM containing 0-50 $\mu \mathrm{M}$ curcumin (Sigma-Aldrich), and cells were incubated for another $24 \mathrm{~h}$. Cell viability was determined using the MTT assay. Briefly, the medium was removed, $100 \mu \mathrm{L}$ of $0.7 \mathrm{mg} / \mathrm{mL}$ MTT (Invitrogen, Waltham, MA, USA) solution in serum-free DMEM was added into each well, and the plates were incubated for 90 min until formazan crystal formation was microscopically visible. At the end of the incubation period, the MTT solution was removed, and $100 \mu \mathrm{L}$ of 
dimethyl sulfoxide (DMSO, Sigma-Aldrich) was added to the wells and gently mixed to solubilize the formazan crystals. The absorbance of the dye was measured using a plate reader (EZ Read 400; Biochrom Cambridge, UK) at $570 \mathrm{~nm}$. Cell viability was calculated using the following formula: cells were washed, and the medium was replaced with serum-free-DMEM for $24 \mathrm{~h}$. Next, a straight scratch line was created across the cell monolayer using a sterile 200$\mu \mathrm{L}$ pipette tip. The medium was then removed, and the cells were incubated in a medium containing DMSO or $1 \mu \mathrm{M}$ curcumin for $24 \mathrm{~h}$. Total RNA extraction was per-

Cell viability $(\%)=($ mean experimental absorbance/mean control absorbance $) \times 100$

\section{Gene expression and qPCR analysis}

Gene expression was determined as previously described [35]. Briefly, hGFs were seeded at $6 \times 10^{5}$ cells per $60-\mathrm{mm}$ dish in DMEM containing 10\% FBS. The following day, the cells were washed with PBS, and the medium was replaced with serum-free DMEM for $24 \mathrm{~h}$. The cells were then incubated with $0-20 \mu \mathrm{M}$ curcumin for $24 \mathrm{~h}$. Then, total RNA extraction was performed and gene expression was evaluated by quantitative polymerase chain reaction (qPCR) as previously described [35]. Briefly, total RNA was extracted and $2 \mu \mathrm{g}$ of total RNA from each sample was reverse transcribed. The cDNA template was amplified for 45 cycles. The primers for qPCR are listed in Table 1. Each reaction was conducted in duplicate. The specificity of the PCR products was verified by agarose gel electrophoresis and melting curve analysis. The expression of each gene was normalized to GAPDH expression using the $2^{-\Delta \Delta \mathrm{Ct}}$ method. The gene expression shown in each figure represents the average of the values from three independent experiments. The qPCR and gene expression analysis were initially performed for all curcumin doses, then the most effective concentration was selected for analysis of the wound healing model.

\section{In vitro wound healing model (scratch assay)}

A scratch assay was performed as previously described $[35,36]$. Briefly, hGFs were seeded in $60-\mathrm{mm}$ dishes in DMEM containing 10\% FBS. On the following day, the

Table 1 Primer sequences used for $\mathrm{qPCR}$

\begin{tabular}{|c|c|}
\hline Gene & Primer sequence \\
\hline TGF- $\beta 1$ & $\begin{array}{l}\text { Forward: 5'-GGATACCAACTATTGCTTCAGCTCC-3' } \\
\text { Reverse:5'-AGGCTCCAAATGTAGGGGCAGGGCC-3' }\end{array}$ \\
\hline TGF- $\beta R I$ & $\begin{array}{l}\text { Forward: 5'-GGTCTTGCCCATCTTCACAT-3' } \\
\text { Reverse: 5'-TCTGTGGCTGAATCATGTCT-3' }\end{array}$ \\
\hline TGF- $\beta R \|$ & $\begin{array}{l}\text { Forward: 5'-GTCTACTCCATGGCTCTGGT-3' } \\
\text { Reverse: 5'-ATCTGGATGCCCTGGTGGTT-3' }\end{array}$ \\
\hline VEGF & $\begin{array}{l}\text { Forward: 5'-AGACCCTGGTGGACATCTTC-3' } \\
\text { Reverse: 5'-TGCATTCACATTTGTTGTGC-3' }\end{array}$ \\
\hline GAPDH & $\begin{array}{l}\text { Forward: 5'-TGAACGGGAAGCTCACTGG-3' } \\
\text { Reverse: 5'-TCCACCACCCTGTTGCTGTA-3' }\end{array}$ \\
\hline
\end{tabular}

formed, and gene expression was evaluated by qPCR. In the ERK signaling inhibitor experiments, the cells were incubated with DMSO or $100 \mathrm{nM}$ PD98059 (Cell Signaling Technology, Danvers, USA) for $1 \mathrm{~h}$ followed by DMSO or $1 \mu \mathrm{M}$ curcumin treatment for $24 \mathrm{~h}$.

\section{Statistical analysis}

The data are presented as mean \pm standard deviation of three independent experiments with gingival fibroblasts from three different subjects in each experimental condition $(n=9)$. Normality test was performed using the Shapiro-Wilk test. Normally distributed data were analyzed using the independent $t$-test or one-way ANOVA followed by Tukey's Honestly Significant Difference test. $p<0.05$ denoted statistical significance.

\section{Results}

\section{Effects of curcumin on hGF viability}

The cell viability of curcumin-treated HGFs was evaluated using the MTT assay. Figure 1 demonstrates that $0.1-20 \mu \mathrm{M}$ curcumin did not alter cell viability, whereas 30 and $50 \mu \mathrm{M}$ curcumin significantly induced concentration-dependent cytotoxicity $(p<0.05)$. Therefore,

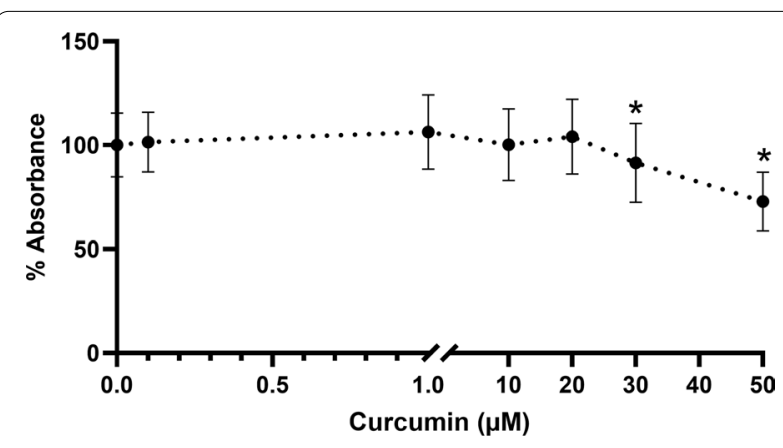

Fig. 1 Cytotoxicity of curcumin in human gingival fibroblasts. Cells were seeded at $5 \times 10^{3}$ cells per well in 96-well plates and treated with varying concentrations of curcumin or DMSO for $24 \mathrm{~h}$. Cell viability was measured using the MTT assay. The data are presented as the mean \pm standard deviation. ${ }^{*} p<0.05$ compared to the control group 
curcumin was used at concentrations of $0.1-20 \mu \mathrm{M}$ in the subsequent experiments.

\section{Effects of curcumin on wound healing-related gene expression}

In unwounded gingival fibroblasts, $0.1-20 \mu \mathrm{M}$ curcumin had no significant effect on TGF- $\beta 1$, TGF- $\beta$ RI, TGF$\beta$ RII, or VEGF expression (Fig. 2). However, our previous study identified $1 \mu \mathrm{M}$ as the optimal curcumin concentration for inducing the expression of other genes, such as keratinocyte growth factor-1 and epidermal growth factor receptor. Therefore, $1 \mu \mathrm{M}$ curcumin was used in our subsequent experiments [35].

\section{Curcumin induced TGF- $\beta 1$, TGF- $\beta$ receptors, and VEGF expression in the in vitro wound healing model}

To investigate the effect of curcumin in the in vitro wound healing model, a scratch assay was performed using hGF monolayers followed by treatment with $1 \mu \mathrm{M}$ curcumin for $24 \mathrm{~h}$. Curcumin significantly upregulated TGF- $\beta 1$, TGF- $\beta$ RI, TGF- $\beta$ RII, and VEGF mRNA expression $(p<0.05)$ in the in vitro wound healing model
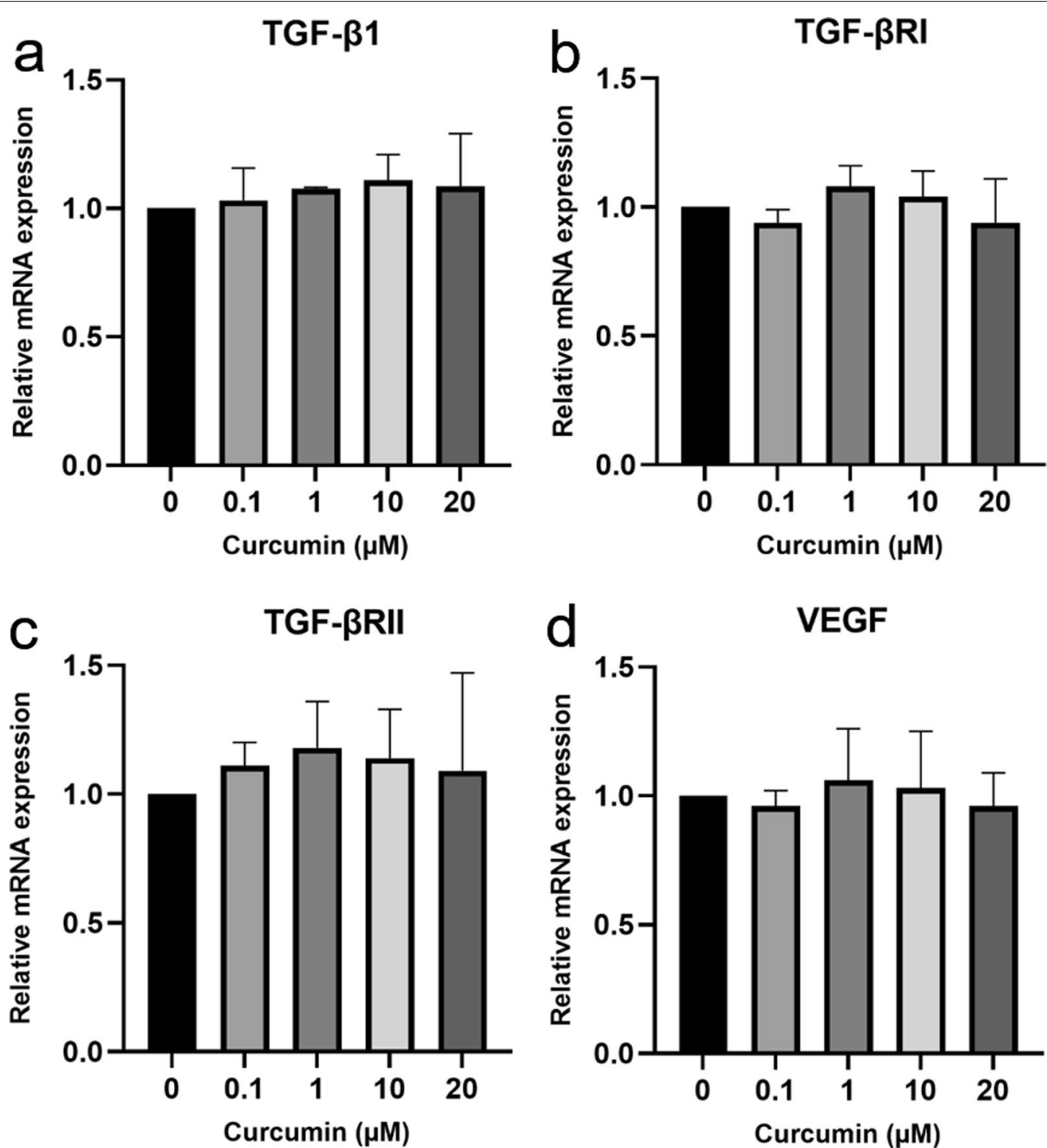

Fig. 2 The expression of transforming growth factor (TGF)- $\beta 1$ (a), type I TGF- $\beta$ receptor (TGF- $\beta$ RI) (b), type II TGF- $\beta$ receptor (TGF- $\beta R$ RI) (c), and vascular endothelial growth factor (VEGF) (d) in human gingival fibroblasts in response to curcumin. Cells were seeded at $6 \times 10^{5}$ cells per plate and treated with varying concentrations of curcumin or DMSO for $24 \mathrm{~h}$. Gene expression was determined by quantitative polymerase chain reaction. The data are presented as the mean \pm standard deviation 
compared to the findings in the vehicle-treated control (Fig. 3).

\section{ERK signaling inhibition decreased curcumin-stimulated gene expression in the in vitro wound healing model}

To determine whether ERK signaling is involved in curcumin-stimulated gene expression, the wounded hGF monolayer was incubated with PD98059 prior to curcumin treatment. PD98059 had no effect on curcumininduced TGF- $\beta 1$ expression (Fig. 4a). However, PD98059 significantly decreased curcumin-induced TGF- $\beta$ RI,
TGF-ßRII, and VEGF mRNA expression (all $p<0.05$, Fig. $4 b-d)$.

\section{Discussion}

In the present study, we first examined the cytotoxicity of curcumin on hGFs. The results indicated that $0.1-$ $20 \mu \mathrm{M}$ curcumin did not significantly affect hGF viability, whereas 30-50 $\mu \mathrm{M}$ curcumin significantly induced concentration-dependent cytotoxicity. Then, we demonstrated that curcumin did not significantly affect TGF$\beta 1$, TGF- $\beta R I$, TGF- $\beta$ RII, or VEGF mRNA expression in unwounded hGFs. Interestingly, in the in vitro wound
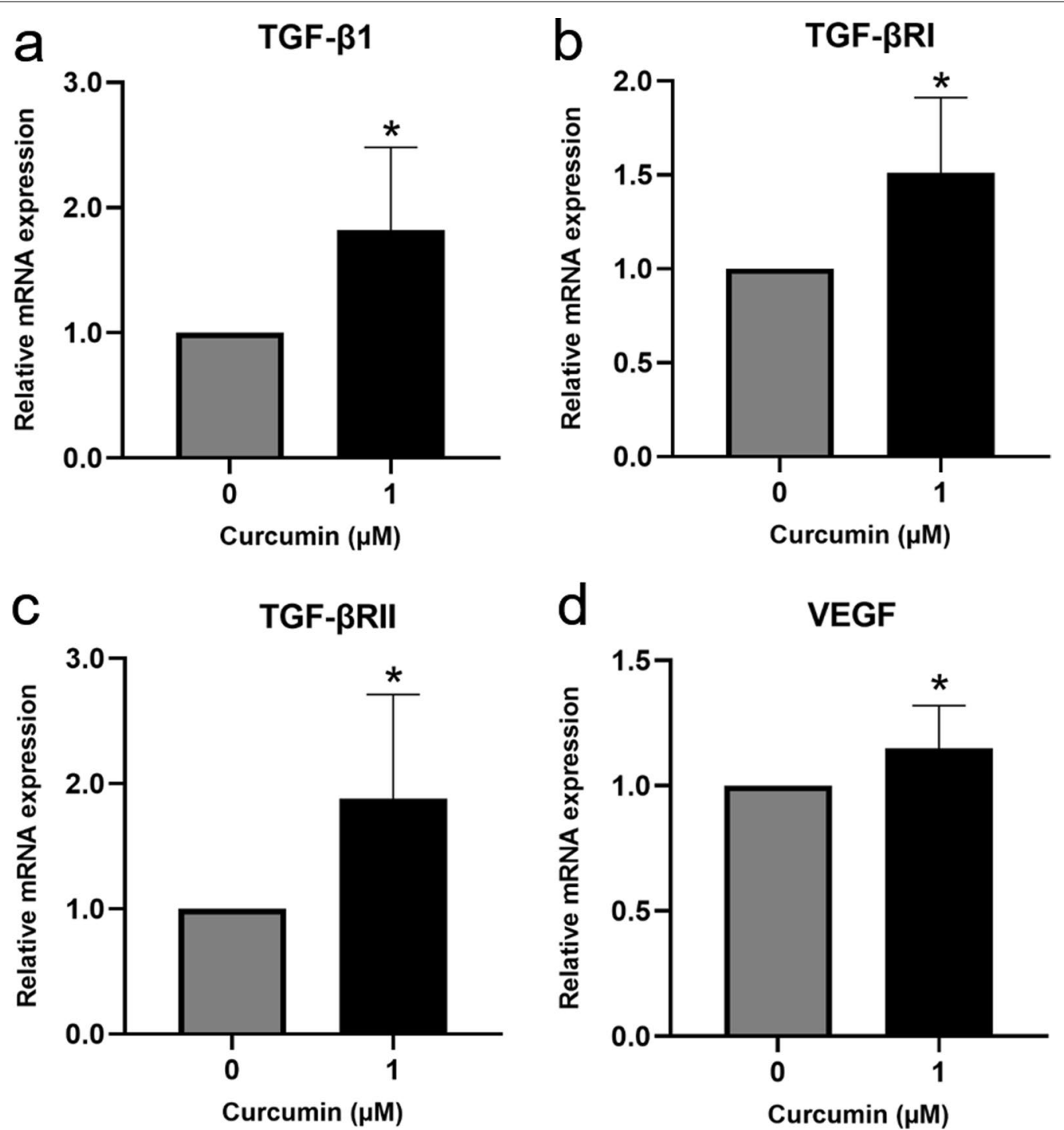

Fig. 3 Curcumin induced transforming growth factor (TGF)- $\beta 1$ (a), type I TGF- $\beta$ receptor (TGF- $\beta$ RI) (b), type II TGF- $\beta$ receptor (TGF- $\beta$ RII) (c), and vascular endothelial growth factor (VEGF) (d) expression in human gingival fibroblasts in the in vitro wound healing model. Cells were seeded at $6 \times 10^{5}$ cells per plate, scratched after monolayer formation, and treated with $1 \mu \mathrm{M}$ curcumin for $24 \mathrm{~h}$. Gene expression was determined by quantitative polymerase chain reaction. The data are presented as the mean \pm standard deviation. ${ }^{*} p<0.05$ compared to the control group 
TGF- $\beta 1$

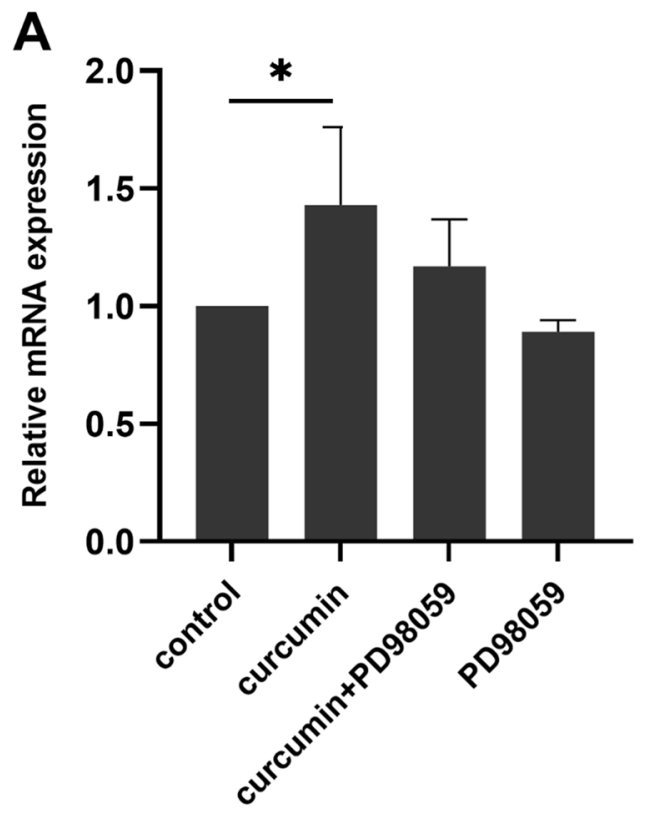

TGF- $\beta R$ II

C

흘

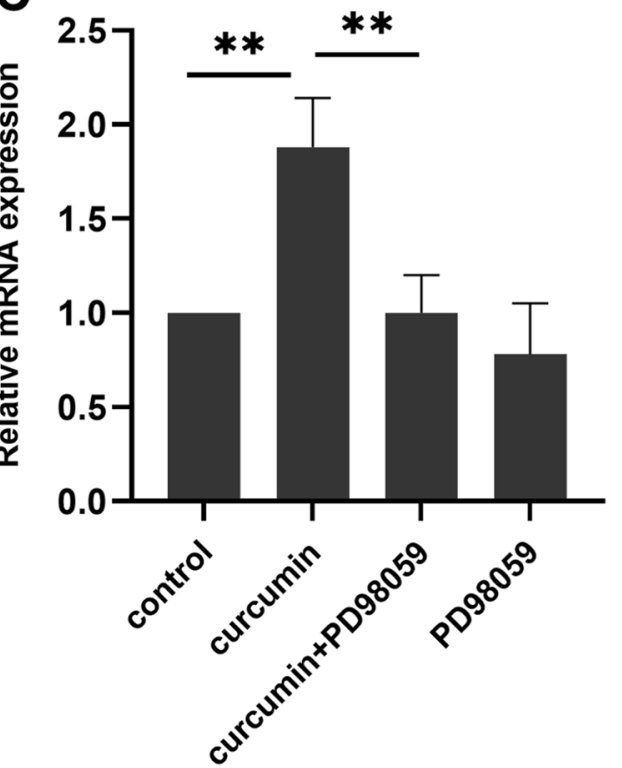

TGF- $\beta R I$

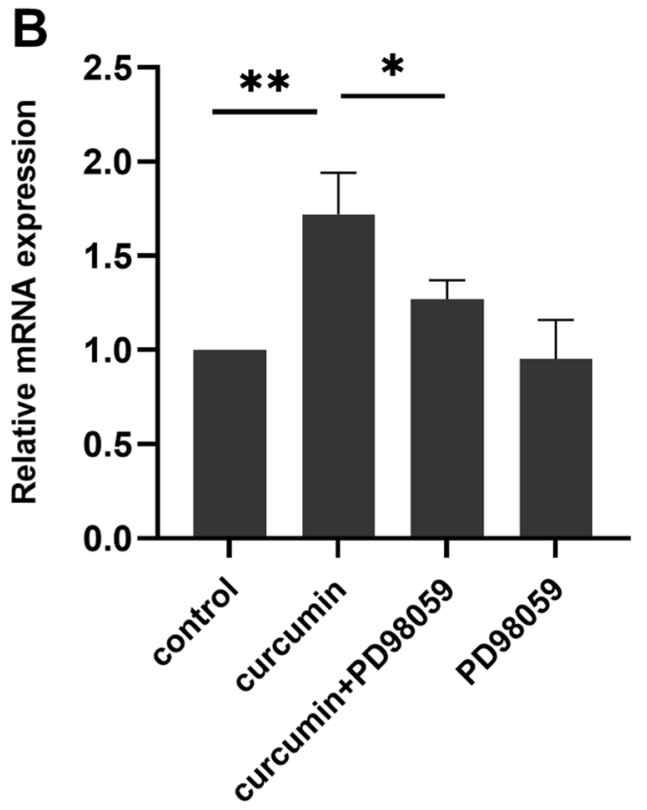

VEGF

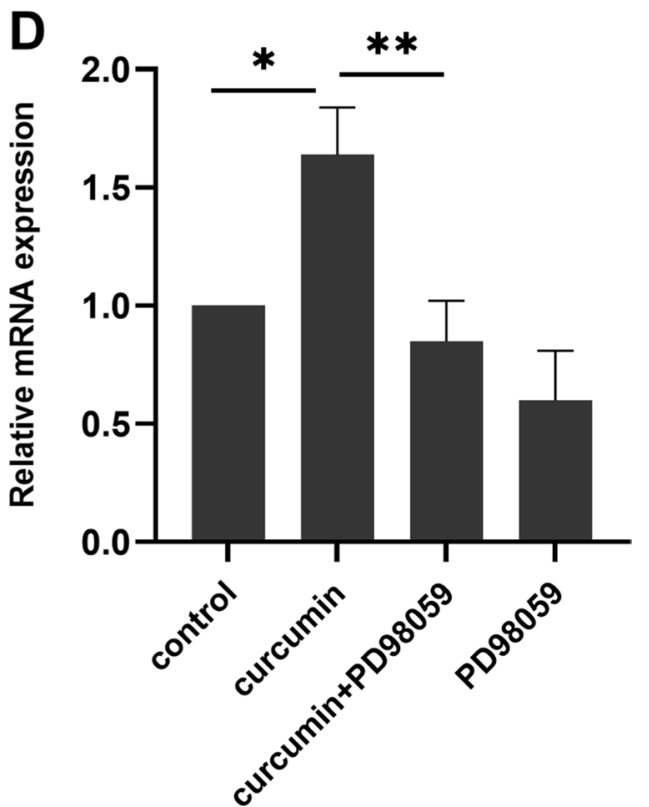

Fig. 4 Effect of PD98059 on curcumin-induced transforming growth factor (TGF)- $\beta 1$ (a), type I TGF- $\beta$ receptor (TGF- $\beta$ RI) (b), type II TGF- $\beta$ receptor (TGF-BRII) (c), and vascular endothelial growth factor (VEGF) (d) expression in human gingival fibroblasts (hGF) in the in vitro wound healing model. Cells were plated at $6 \times 10^{5}$ cells per plate in tissue culture dishes. The wounded hGF culture was treated with $100 \mathrm{nM}$ PD98059 for $1 \mathrm{~h}$ prior to $1 \mu \mathrm{M}$ curcumin treatment for $24 \mathrm{~h}$. Gene expression was determined by quantitative polymerase chain reaction. The data are presented as the mean \pm standard deviation. ${ }^{*} p<0.05 .{ }^{* *} p<0.001$ 
healing model, curcumin significantly stimulated TGF$\beta 1$, TGF- $\beta$ RI, and TGF- $\beta$ RII expression in hGFs.

Previous studies reported that TGF- $\beta 1$ expression was remarkably lower in non-healing wounds than in normal healing ulcers [37, 38]. Moreover, many studies reported increased wound healing when the wound was treated with exogenous TGF- $\beta 1$ [39-41]. The TGF- $\beta$ receptors are localized on the cell surface of several cell types, including fibroblasts and endothelial cells [42, 43]. In previous research, TGF- $\beta$ receptor expression increased after injury, with the highest expression observed on day 14 and declining by day 56 after wounding [44]. A previous study demonstrated that curcumin differentially regulated TGF- $\beta$ and its receptors. Specifically, curcumin induced TGF- $\beta 1$ and TGF- $\beta$ RII expression in unimpaired and impaired healing cutaneous wounds, whereas TGF$\beta R I$ expression was increased only in impaired healing wounds 7 days after wounding [8]. We also reported the similar differential regulation of TGF- $\beta$ and its receptors by curcumin in which curcumin increased the expression of TGF- $\beta$ and its receptors only in the in vitro wound healing model but not in the unwounded gingival fibroblasts, supporting the concept that curcumin promotes healing in wounded tissues [8].

VEGF is a strong positive regulator of angiogenesis that stimulates endothelial cells for new blood vessel formation [45]. The VEGF receptor is expressed mainly on endothelial cells [46]. VEGF-A deficient mice exhibit delayed wound closure because of reduced vessel density [47]. In another study, curcumin enhanced blood vessel formation and promoted wound healing by increasing VEGF and TGF- $\beta 1$ expression in diabetic rat granulation tissue [48]. In addition to cutaneous wounds, curcumin promoted indomethacin-induced gastric ulcer healing by increasing matrix metalloproteinase-2, TGF- $\beta$, and VEGF expression [49]. Correspondingly, we demonstrated for the first time that curcumin significantly increased VEGF expression in the in vitro hGF wound healing model. However, VEGF expression was not affected in the unwounded cell monolayer, suggesting that curcumin regulates gene expression in a controlled "as needed" manner because VEGF upregulation is unnecessary in unwounded tissues. However, the mechanism by which curcumin differentially regulates gene expression under physiological and wounded conditions remains to be elucidated.

Curcumin regulates gene expression in part by modulating the phosphorylation activity of MAPK [33]. The MAPK pathway has an important function in transducing extracellular signals to cellular responses [50]. The MAPK family comprises MAPK (also known as ERK), C-Jun $\mathrm{N}$-terminal kinase/stress activated protein kinase, and p38 MAPK [50]. MAPK is involved in many cell functions, especially in regulating cell migration and proliferation [51, 52]. A previous study demonstrated that ERK signaling is important for the proliferative phase of cutaneous wound healing by promoting keratinocyte proliferation and migration [53]. Inhibition of either the ERK1/2 or p38 pathway resulted in delayed corneal epithelial wound healing [54]. In the present study, curcumin-stimulated TGF- $\beta$ RI, TGF- $\beta$ RII, and VEGF expression was significantly attenuated by an ERK signaling inhibitor, PD98059, while TGF- $\beta 1$ expression was not affected. These data suggest that curcumin regulates TGF- $\beta$ RI, TGF- $\beta$ RII, and VEGF expression in hGFs by modulating the ERK pathway. Our findings are consistent with our previous report that curcumin-induced type I collagen and EGFR expression in hGFs also requires ERK activation [35]. However, most previous studies investigated the effect of curcumin in various cancer cell lines and observed that curcumin inhibited ERK signaling [33]. Taken together, these findings suggest that curcumin might differentially regulate ERK in normal cells and cancer cells; however, the exact mechanism requires further investigation.

Although the scratch assay used in this study is not an ideal wound healing model, it has been widely used to study the effects of many drugs and biological factors on keratinocyte and fibroblast migration $[36,55]$. At the cellular level, scratching induces an increase in reactive oxygen species, Nrf2 protein, and stress response genes, including heat shock protein 70 and heme oxygenase-1, in breast cancer cells [36]. The antioxidative property of curcumin may reduce ROS production in the injured cells, which may be one of the mechanisms by which curcumin promotes wound healing. Further investigations are required to explore this possibility in hGFs.

Mechanical injuries from scratching cause the injured cells to produce chemical stimuli that diffuse to neighboring cells. In addition, scratching induces an increase in intracellular calcium in the injured cells which is transmitted through cell-cell junctions to nearby cells that are not damaged. This calcium wave propagates into cells that are distant from the wound edge [56]. Increased intracellular calcium activates multiple signaling pathways, resulting in alteration of gene expression [57]. These data suggest that mechanical injuries may alter gene expression not only in cells around the wound edge, but also in those located a long distance away. A previous study demonstrated that curcumin dose-dependently decreased the intracellular calcium level in colorectal carcinoma cells [58]. Whether curcumin could regulate the changes in intracellular calcium level induced by mechanical injuries requires further investigation. Because wound healing is a complex process and requires interaction between several cell types, the scratch assay 
using one cell type only mimics the mechanical injury to these cells. Owing to this limitation, further investigation is required to support our findings on the effect of curcumin on gene expression in this wound healing model.

\section{Conclusions}

Curcumin significantly upregulated TGF- $\beta 1$, TGF- $\beta$ RI, TGF- $\beta$ RII, and VEGF mRNA expression in the in vitro hGF wound healing model. The ERK pathway is crucial for curcumin-stimulated TGF- $\beta$ RI, TGF- $\beta$ RII, and VEGF mRNA expression. Further investigations are required to examine other mechanisms of curcumin that are responsible for promoting gingival wound healing. Our findings support the therapeutic potential of curcumin as a wound healing agent for treating gingival ulcers.

\section{Abbreviations}

hGFs: Human gingival fibroblasts; TGF- $\beta 1$ : Transforming growth factor beta 1 ; TGF- $\beta$ RI: Type I TGF- $\beta$ receptor; TGF- $\beta$ RII: Type II TGF- $\beta$ receptor; VEGF: Vascular endothelial growth factor; MTT: (3-(4,5-Dimethylthiazol-2-yl)-2,5-diphenyltetrazolium bromide); ERK: Extracellular signal regulated kinase; MAPK: Mitogenactivated protein kinase; DMEM: Dulbecco's Modified Eagle's medium; FBS: Fetal bovine serum; PBS: Phosphate-buffered saline; DMSO: Dimethyl sulfoxide; GAPDH: Glyceraldehyde-3-phosphate dehydrogenase.

\section{Acknowledgements}

The authors thank Dr. Kevin Tompkins for his assistance in reviewing the manuscript.

\section{Authors' contributions}

AR contributed to study conceptualization, data acquisition, statistical analysis, and original draft preparation. SS contributed to study conceptualization, data interpretation, reviewing and editing the manuscript. Both authors read and approved the final manuscript.

\section{Funding}

This study was supported by the Graduate Research Grant 2018, National Research Council of Thailand which had no role in the design of the study and the collection, analysis, and interpretation of data or in writing the manuscript.

\section{Availability of data and materials}

The datasets generated and/or analyzed during the current study are available in the Figshare repository, https://doi.org/10.6084/m9.figshare.15073029.

\section{Declarations}

\section{Ethics approval and consent to participate}

All procedures performed in studies involving human participants were in accordance with the ethical standards of the Ethics Committee at the Faculty of Dentistry, Chulalongkorn University. Informed consent was obtained from all individual participants included in the study.

\section{Consent for publication}

Not applicable.

\section{Competing interests}

The authors declare that they have no competing interests.

\section{Author details}

${ }^{1}$ Graduate Program in Pediatric Dentistry, Faculty of Dentistry, Chulalongkorn University, Bangkok 10330, Thailand. 'Present Address: Banphue Hospital, 134 Moo 2, Plubphue Road, Banphue District, Udonthani 41160, Thailand. ${ }^{3}$ Department of Physiology, Faculty of Dentistry, Chulalongkorn University, Bangkok 10330, Thailand.
Received: 14 July 2021 Accepted: 6 October 2021

Published online: 17 October 2021

\section{References}

1. Pastar I, Stojadinovic O, Yin NC, Ramirez H, Nusbaum AG, Sawaya A, Patel SB, Khalid L, Isseroff RR, Tomic-Canic M. Epithelialization in wound healing: a comprehensive review. Adv Wound Care. 2014;3(7):445-64.

2. Diegelmann RF, Evans MC. Wound healing: an overview of acute, fibrotic and delayed healing. Front Biosci J Virtual Library. 2004;9:283-9.

3. Aukhil I. Biology of wound healing. Periodontol. 2000;22(1):44-50.

4. Barrientos S, Stojadinovic O, Golinko MS, Brem H, Tomic-Canic M. Growth factors and cytokines in wound healing. Wound Repair Regen. 2008;16(5):585-601.

5. Lee HS, Kooshesh F, Sauder DN, Kondo S. Modulation of TGF-beta 1 production from human keratinocytes by UVB. Exp Dermatol. 1997:6(2):105-10.

6. Eppley BL, Woodell JE, Higgins J. Platelet quantification and growth factor analysis from platelet-rich plasma: implications for wound healing. Plast Reconstr Surg. 2004;114(6):1502-8.

7. Wu L, Yu YL, Galiano RD, Roth SI, Mustoe TA. Macrophage colony-stimulating factor accelerates wound healing and upregulates TGF-beta1 mRNA levels through tissue macrophages. J Surg Res. 1997;72(2):162-9.

8. Mani H, Sidhu GS, Kumari R, Gaddipati JP, Seth P, Maheshwari RK. Curcumin differentially regulates TGF-beta1, its receptors and nitric oxide synthase during impaired wound healing. BioFactors (Oxford, England). 2002:16(1-2):29-43.

9. Tirado-Rodriguez B, Ortega E. TGF- $\beta$ : an important mediator of allergic disease and a molecule with dual activity in cancer development. J Immunol Res. 2014;2014:318481.

10. Pakyari M, Farrokhi A, Maharlooei MK, Ghahary A. Critical role of transforming growth factor beta in different phases of wound healing. Adv Wound Care. 2013;2(5):215-24.

11. Montesano R, Orci L. Transforming growth factor beta stimulates collagen-matrix contraction by fibroblasts: implications for wound healing. Proc Natl Acad Sci USA. 1988;85(13):4894-7.

12. Desmouliere A, Geinoz A, Gabbiani F, Gabbiani G. Transforming growth factor-beta 1 induces alpha-smooth muscle actin expression in granulation tissue myofibroblasts and in quiescent and growing cultured fibroblasts. J Cell Biol. 1993;122(1):103-11.

13. Klass BR, Grobbelaar AO, Rolfe KJ. Transforming growth factor beta1 signalling, wound healing and repair: a multifunctional cytokine with clinical implications for wound repair, a delicate balance. Postgrad Med J. 2009;85(999):9-14.

14. Saaristo A, Tammela T, Farkkila A, Karkkainen M, Suominen E, Yla-Herttuala S, Alitalo K. Vascular endothelial growth factor-C accelerates diabetic wound healing. Am J Pathol. 2006;169(3):1080-7.

15. Namiki A, Brogi E, Kearney M, Kim EA, Wu T, Couffinhal T, Varticovski L, Isner JM. Hypoxia induces vascular endothelial growth factor in cultured human endothelial cells. J Biol Chem. 1995;270(52):31189-95.

16. Detsch R, Stoor P, Grunewald A, Roether JA, Lindfors NC, Boccaccini AR. Increase in VEGF secretion from human fibroblast cells by bioactive glass S53P4 to stimulate angiogenesis in bone. J Biomed Mater Res A 2014;102(11):4055-61.

17. Banks RE, Forbes MA, Kinsey SE, Stanley A, Ingham E, Walters C, Selby PJ. Release of the angiogenic cytokine vascular endothelial growth factor (VEGF) from platelets: significance for VEGF measurements and cancer biology. Br J Cancer. 1998;77(6):956-64.

18. Gaudry M, Bregerie O, Andrieu V, El Benna J, Pocidalo MA, Hakim J. Intracellular pool of vascular endothelial growth factor in human neutrophils. Blood. 1997;90(10):4153-61.

19. Berse B, Brown LF, Van de Water L, Dvorak HF, Senger DR. Vascular permeability factor (vascular endothelial growth factor) gene is expressed differentially in normal tissues, macrophages, and tumors. Mol Biol Cell. 1992:3(2):211-20.

20. Brown LF, Yeo KT, Berse B, Yeo TK, Senger DR, Dvorakvan de Water HFL. Expression of vascular permeability factor (vascular endothelial growth factor) by epidermal keratinocytes during wound healing. J Exp Med. 1992;176(5):1375-9. 
21. Bao P, Kodra A, Tomic-Canic M, Golinko MS, Ehrlich HP, Brem H. The role of vascular endothelial growth factor in wound healing. J Surg Res. 2009;153(2):347-58.

22. Sharma RA, Euden SA, Platton SL, Cooke DN, Shafayat A, Hewitt HR, Marczylo TH, Morgan B, Hemingway D, Plummer SM, et al. Phase I clinical trial of oral curcumin: biomarkers of systemic activity and compliance. Clin Cancer Res Off J Am Assoc Cancer Res. 2004;10(20):6847-54.

23. Chattopadhyay I, Biswas K, Bandyopadhyay U, Banerjee RK. Turmeric and curcumin: Biological actions and medicinal applications. Current Sci Bangalore. 2004;87:44-53.

24. Liang G, Yang S, Zhou H, Shao L, Huang K, Xiao J, Huang Z, Li X. Synthesis, crystal structure and anti-inflammatory properties of curcumin analogues. Eur J Med Chem. 2009;44(2):915-9.

25. Meng B, Li J, Cao H. Antioxidant and antiinflammatory activities of curcumin on diabetes mellitus and its complications. Curr Pharm Des. 2013;19(11):2101-13.

26. Tyagi P, Singh M, Kumari H, Kumari A, Mukhopadhyay K. Bactericidal activity of curcumin I is associated with damaging of bacterial membrane. PLoS ONE. 2015;10(3):e0121313.

27. Aggarwal S, Takada Y, Singh S, Myers JN, Aggarwal BB. Inhibition of growth and survival of human head and neck squamous cell carcinoma cells by curcumin via modulation of nuclear factor-kappaB signaling. Int J Cancer. 2004;111(5):679-92.

28. Akbik D, Ghadiri M, Chrzanowski W, Rohanizadeh R. Curcumin as a wound healing agent. Life Sci. 2014;116(1):1-7.

29. Lim YS, Kwon SK, Park JH, Cho CG, Park SW, Kim WK. Enhanced mucosal healing with curcumin in animal oral ulcer model. Laryngoscope. 2016;126(2):E68-73.

30. Manifar S, Obwaller A, Gharehgozloo A, Boorboor Shirazi Kordi H, Akhondzadeh S. Curcumin gel in the treatment of minor aphthous ulcer: a randomized, placebo-controlled trial. J Med Plants. 2012;1(41):40-5.

31. Gopinath D, Ahmed MR, Gomathi K, Chitra K, Sehgal PK, Jayakumar R. Dermal wound healing processes with curcumin incorporated collagen films. Biomaterials. 2004;25(10):1911-7.

32. Bhagavathula N, Warner RL, DaSilva M, McClintock SD, Barron A, Aslam $\mathrm{MN}$, Johnson KJ, Varani J. A combination of curcumin and ginger extract improves abrasion wound healing in corticosteroid-impaired hairless rat skin. Wound Repair Regen. 2009;17(3):360-6.

33. Shishodia S. Molecular mechanisms of curcumin action: gene expression. BioFactors. 2013;39(1):37-55.

34. Fang G, Chen S, Huang Q, Chen L, Liao D. Curcumin suppresses cardiac fibroblasts activities by regulating the proliferation and cell cycle via the inhibition of the p38 MAPKJERK signaling pathway. Mol Med Rep. 2018;18(2):1433-8.

35. Rujirachotiwat A, Suttamanatwong S. Curcumin Promotes Collagen Type I, Keratinocyte Growth Factor-1, and Epidermal Growth Factor Receptor Expressions in the In Vitro Wound Healing Model of Human Gingival Fibroblasts. Eur J Dent. 2021;15(1):63-70.

36. Riahi R, Long M, Yang Y, Dean Z, Zhang DD, Slepian MJ, Wong PK. Single cell gene expression analysis in injury-induced collective cell migration. Integr Biol (Camb). 2014;6(2):192-202.

37. Cowin AJ, Hatzirodos N, Holding CA, Dunaiski V, Harries RH, Rayner TE, Fitridge R, Cooter RD, Schultz GS, Belford DA. Effect of healing on the expression of transforming growth factor beta(s) and their receptors in chronic venous leg ulcers. J Investig Dermatol. 2001;117(5):1282-9.

38. Jude EB, Blakytny R, Bulmer J, Boulton AJ, Ferguson MW. Transforming growth factor-beta 1, 2, 3 and receptor type I and II in diabetic foot ulcers. Diabetic Med J Br Diabetic Assoc. 2002;19(6):440-7.

39. Quaglino D Jr, Nanney LB, Ditesheim JA, Davidson JM. Transforming growth factor-beta stimulates wound healing and modulates extracellular matrix gene expression in pig skin: incisional wound model. J Investig Dermatol. 1991;97(1):34-42.

40. Quaglino D Jr, Nanney LB, Kennedy R, Davidson JM. Transforming growth factor-beta stimulates wound healing and modulates extracellular matrix gene expression in pig skin. I. Excisional wound model. Lab Investig J Tech Methods Pathol. 1990;63(3):307-19.

41. Mustoe TA, Pierce GF, Thomason A, Gramates P, Sporn MB, Deuel TF. Accelerated healing of incisional wounds in rats induced by transforming growth factor-beta. Science. 1987;237(4820):1333-6.

42. Goumans MJ, Valdimarsdottir G, Itoh S, Lebrin F, Larsson J, Mummery C, Karlsson S, ten Dijke P. Activin receptor-like kinase (ALK)1 is an antagonistic mediator of lateral TGFbeta/ALK5 signaling. Mol Cell. 2003;12(4):817-28.

43. Petridou S, Maltseva O, Spanakis S, Masur SK. TGF-beta receptor expression and smad2 localization are cell density dependent in fibroblasts. Investig Ophthalmol Vis Sci. 2000;41(1):89-95.

44. Ngo M, Pham H, Longaker MT, Chang J. Differential expression of transforming growth factor-beta receptors in a rabbit zone II flexor tendon wound healing model. Plast Reconstr Surg. 2001;108(5):1260-7.

45. Leung DW, Cachianes G, Kuang WJ, Goeddel DV, Ferrara N. Vascular endothelial growth factor is a secreted angiogenic mitogen. Science. 1989:246(4935):1306-9

46. Jebreel A, England J, Bedford K, Murphy J, Karsai L, Atkin S. Vascular endothelial growth factor (VEGF), VEGF receptors expression and microvascular density in benign and malignant thyroid diseases. Int J Exp Pathol. 2007:88(4):271-7.

47. Rossiter H, Barresi C, Pammer J, Rendl M, Haigh J, Wagner EF, Tschachler E. Loss of vascular endothelial growth factor a activity in murine epidermal keratinocytes delays wound healing and inhibits tumor formation. Cancer Res. 2004;64(10):3508-16.

48. Kant V, Gopal A, Kumar D, Pathak NN, Ram M, Jangir BL, Tandan SK, Kumar D. Curcumin-induced angiogenesis hastens wound healing in diabetic rats. J Surg Res. 2015;193(2):978-88.

49. Sharma AV, Ganguly K, Paul S, Maulik N, Swarnakar S. Curcumin heals indomethacin-induced gastric ulceration by stimulation of angiogenesis and restitution of collagen fibers via VEGF and MMP-2 mediated signaling. Antioxid Redox Signaling. 2012;16(4):351-62.

50. Zhang W, Liu HT. MAPK signal pathways in the regulation of cell proliferation in mammalian cells. Cell Res. 2002;12(1):9-18.

51. He M, Xue ZM, Li J, Zhou BQ. Breviscapine inhibits high glucose-induced proliferation and migration of cultured vascular smooth muscle cells of rats via suppressing the ERK1/2 MAPK signaling pathway. Acta Pharmacol Sin. 2012;33(5):606-14.

52. Klemke RL, Cai S, Giannini AL, Gallagher PJ, de Lanerolle P, Cheresh DA. Regulation of cell motility by mitogen-activated protein kinase. J Cell Biol. 1997:137(2):481-92.

53. Shibata S, Tada Y, Asano Y, Hau CS, Kato T, Saeki H, Yamauchi T, Kubota N, Kadowaki T, Sato S. Adiponectin regulates cutaneous wound healing by promoting keratinocyte proliferation and migration via the ERK signaling pathway. J Immunol (Baltimore, Md: 1950). 2012;189(6):3231-41.

54. Sharma GD, He J, Bazan HE. p38 and ERK1/2 coordinate cellular migration and proliferation in epithelial wound healing: evidence of cross-talk activation between MAP kinase cascades.J Biol Chem. 2003;278(24):21989-97.

55. Hakkinen L, Uitto VJ, Larjava H. Cell biology of gingival wound healing. Periodontol. 2000;24:127-52.

56. Sammak PJ, Hinman LE, Tran POT, Sjaastad MD, Machen TE. How do injured cells communicate with the surviving cell monolayer? J Cell Sci. 1997;110:465-75.

57. Ghilardi SJ, O'Reilly BM, Sgro AE. Intracellular signaling dynamics and their role in coordinating tissue repair. Wiley Interdiscipl Rev Syst Biol Med. 2020;12(3):e1479.

58. Chen YC, Kuo TC, Lin-Shiau SY, Lin JK. Induction of HSP70 gene expression by modulation of $\mathrm{Ca}(+2)$ ion and cellular $\mathrm{p} 53$ protein by curcumin in colorectal carcinoma cells. Mol Carcinog. 1996;17(4):224-34.

\section{Publisher's Note}

Springer Nature remains neutral with regard to jurisdictional claims in published maps and institutional affiliations. 